\title{
Effect of planting technique and amendment type on pearl millet yield, nutrient uptake, and water use on degraded land in Niger
}

\author{
D. Fatondji ${ }^{1}$, C. Martius ${ }^{2, *}$, C.L. Bielders ${ }^{3}$, P.L.G. Vlek ${ }^{2}$, A. Bationo ${ }^{4}$ and B. Gerard ${ }^{1}$ \\ ${ }^{1}$ ICRISAT-Niger, BP 12404, Niamey, Niger; ${ }^{2} Z E F$, UNI-Bonn, Walter-Flex-Street 3, D-53113, Bonn, \\ Germany; ${ }^{3}$ Université catholique de Louvain (ULC), Croix du Sud 2, boite 2, B-1348, Louvain-la-Neuve, \\ Belgium; ${ }^{4}$ TSBF-CIAT, c/o ICRAF, P.O, Box 30677, Nairobi, Kenya; *Author for correspondence (e-mail: \\ c.martius@uni-bonn.de)
}

Key words: Agronomic efficiency, Indigenous technology, Nutrient use efficiency, Planting pit, Rainfall use efficiency, Uptake, Zai

\begin{abstract}
Due to increased population pressure and limited availability of fertile land, farmers on desert fringes increasingly rely on marginal land for agricultural production, which they have learned to rehabilitate with different technologies for soils and water conservation. One such method is the indigenous zai technique used in the Sahel. It combines water harvesting and targeted application of organic amendments by the use of small pits dug into the hardened soil. To study the resource use efficiency of this technique, experiments were conducted 1999-2000, on-station at ICRISAT in Niger, and on-farm at two locations on degraded lands. On-station, the effect of application rate of millet straw and cattle manure on millet dry matter production was studied. On-farm, the effects of organic amendment type (millet straw and cattle manure, at the rate of $300 \mathrm{~g}$ per plant) and water harvesting (with and without water harvesting) on millet grain yield, dry matter production, and water use were studied. First, the comparison of zai vs. flat planting, both unamended, resulted in a 3- to 4-fold (in one case, even 19fold) increase in grain yield on-farm in both years, which points to the yield effects of improved water harvesting in the zai alone. Zai improved the water use efficiency by a factor of about 2 . The yields increased further with the application of organic amendments. Manure resulted in 2-68 times better grain yields than no amendment and 2-7 times better grain yields than millet straw (higher on the more degraded soils). Millet dry matter produced per unit of manure $\mathrm{N}$ or $\mathrm{K}$ was higher than that of millet straw, a tendency that was similar for all rates of application. Zai improved nutrient uptake in the range of $43-64 \%$ for $\mathrm{N}, 50-87 \%$ for $\mathrm{P}$ and $58-66 \%$ for $\mathrm{K}$. Zai increased grain yield produced per unit $\mathrm{N}$ ( 8 vs. $\left.5 \mathrm{~kg} \mathrm{~kg}^{-1}\right)$ and $\mathrm{K}\left(10\right.$ vs. $\left.6 \mathrm{~kg} \mathrm{~kg}^{-1}\right)$ compared to flat; so is the effect of cattle manure compared to millet straw ( 9 vs. $4 \mathrm{~kg} \mathrm{~kg}^{-1}$, and 14 vs. $3 \mathrm{~kg} \mathrm{~kg}^{-1}$ ), respectively, Therefore zai shows a good potential for increasing agronomic efficiency and nutrient use efficiency. Increasing the rate of cattle manure application from 1 to $3 \mathrm{tha}^{-1}$ increased the yield by $115 \%$ TDM, but increasing the manure application rate further from 3 to $5 \mathrm{t} \mathrm{ha}^{-1}$ only gave an additional $12 \%$ yield increase, which shows that optimum application rates are around $3 \mathrm{t} \mathrm{ha}^{-1}$.
\end{abstract}

This article has been previously published in the journal "Nutrient Cycling in Agroecosystems" Volume 76 Issues 2-3. 


\section{Introduction}

Sustainable land use implies harmony between man's use of land and the land's ability to maintain its quality. Once this balance is upset, land degradation occurs (Katyal and Vlek 2000). Agricultural land degradation is one of the major problems facing agricultural production nowadays. According to the Global Land Assessment of Degradation (GLASOD) (Oldeman et al. 1990) $38 \%$ of the world's total cropland has been degraded since the 1950s and in Africa, $65 \%$ of the cropland is degraded to some extent. As Sundquist (2004) reported that desertification along the Sahara desert proceeds at an estimated $1000 \mathrm{~km}^{2}$ every year, these areas are likely to have increased significantly since the GLASOD assessment. In the Sahelian zone, soil fertility restoration through the vegetative fallow system is becoming increasingly ineffective due to population pressure, which leads to shorter fallow periods or simply to land abandonment (Amissah-Arthur et al. 2000). Limited availability of fertile land forces farmers to rely on marginal or even degraded lands for agricultural production.

Zai is one of several techniques available for rehabilitation of degraded lands. To prepare the zai, farmers dig small pits in the soil to collect water, wind-driven soil particles, and plant debris around the plant. About two handfuls (the equivalent to $300 \mathrm{~g}$ ) of organic amendments such as millet straw, cattle manure or their composted form are typically added to the pits (Roose et al. 1992, 1993; Kaboré 1995; Ouédraogo and Kaboré 1996). The technique thus combines water harvesting with nutrient management practices. As locally available material is used, small-scale farmers who are the major food producers in the Sahel (Roose et al. 1992) are easily able to implement it. The main investment required by the technology is manpower for digging the zai holes, but the work is done during the dry period of the year when the farmers can invest some spare time. Previous studies have shown that zai promotes crop production on highly degraded soils and helps alleviate the adverse effect of dry spells, which are frequent during the cropping period in the Sahel (Roose et al. 1993; Hassan, 1996). However, no attempts have been made to study the resource use efficiency of the technology. To address this gap, we hypothesized that both the water collected in the pit and the nutrient released from the amendment (which is concentrated at the rooting zone of the crop) induce better plant development and yield, resulting in higher nutrient and water use efficiencies. To address this hypothesis in the present study, experiments were carried out in the Sahelian zone of Niger, on-station under controlled water supply in 1999, and on-farm at two locations during the rainy seasons 1999 and 2000. The objective of the on-station experiment was to determine the optimum application rate of organic amendments for pearl millet (Pennisetum glaucum) production as a function of the type of amendment. The objective of the on-farm experiment was to study resource use efficiency of millet under rainfed conditions in the zai system as compared to planting on flat soil.

\section{Material and methods}

\section{Site description}

The on-station experiment was conducted under controlled water supply at the ICRISAT research station at Sadoré $\left(13^{\circ} 15^{\prime} \mathrm{N}, 2^{\circ} 17^{\prime} \mathrm{E}\right)$ in Niger from March to May 1999. Longterm average annual rainfall at this site is $550 \mathrm{~mm}$, which falls between June and September. Monthly temperature varies between 25 and $41{ }^{\circ} \mathrm{C}$. The soils are classified as psammentic paleustalf (West et al. 1984), acidic with relatively high $\mathrm{Al}$ saturation and very high sand content (Table 1). The experiment was conducted on a field that had been subject to severe wind and water erosion for a period of 4 years, and that had developed extensive erosion crusts (Casenave and Valentin 1989), locally known as "Gangani", characteristic of severely degraded land.

The two on-farm yield trials were conducted during the rainy seasons 1999 and 2000 at Damari $\left(13^{\circ} 12^{\prime} \mathrm{N}\right.$ and $\left.2^{\circ} 14^{\prime} \mathrm{E}\right)$ and Kakassi $\left(13^{\circ} 50^{\prime} \mathrm{N}\right.$ and $\left.1^{\circ} 29^{\prime} \mathrm{E}\right)$. Long-term average annual rainfall and monthly temperature amplitude at Damari are similar to conditions at the ICRISAT research station. The soil at Damari is classified as kanhaplic Haplustult (Soil Survey Staff 1998). It is acidic, with $84 \%$ sand content and relatively low effective cation exchange capacity (ECEC). The vegetation was an open bush with scattered trees. 
Table 1. Selected initial soil properties of the experimental fields at Sadoré, Damari and Kakassi, (0-20 cm soil depth).

\begin{tabular}{|c|c|c|c|}
\hline Soil characteristics & Sadoré & Damari & Kakassi \\
\hline $\mathrm{pH}\left(\mathrm{H}_{2} 0\right)$ & 4.5 & 4.2 & 6.4 \\
\hline $\mathrm{pH}(\mathrm{KC} 1)$ & 3.9 & 3.9 & 5.4 \\
\hline $\begin{array}{l}\text { Exchangeable base } \\
\left(\mathrm{cmol} \mathrm{kg}^{-1}\right)\end{array}$ & 0.4 & 1.7 & 7.9 \\
\hline 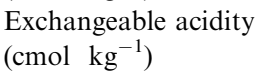 & 0.7 & 1.1 & 0.04 \\
\hline $\operatorname{ECEC}^{\mathrm{a}}\left(\mathrm{cmol} \mathrm{kg}^{-1}\right)$ & 1.0 & 2.8 & 7.9 \\
\hline $\mathrm{Al}$ saturation $(\%)$ & 47 & 29 & 0 \\
\hline Base saturation $(\%)$ & 37 & 61 & 99 \\
\hline P-Bray $1\left(\mathrm{mg} \mathrm{kg}^{-1}\right)$ & 2.3 & 2 & 0.8 \\
\hline $\mathrm{C}$ org $(\%)$ & 0.1 & 0.2 & 0.2 \\
\hline Total N (mg kg$\left.{ }^{-1}\right)$ & 120 & 116 & 169 \\
\hline Bulk density $\left(\mathrm{kg} \mathrm{m}^{-3}\right)$ & 1.5 & 1.6 & 1.8 \\
\hline Sand $(\%)$ & 92 & 84 & 69 \\
\hline Silt $(\%)$ & 3 & 3 & 6 \\
\hline Clay (\%) & 5 & 13 & 25 \\
\hline
\end{tabular}

${ }^{a}$ Effective Cation Exchange Capacity.

The selected field had been left fallow for 3 years prior to the experiment. In addition to small patches of loose sand deposits, which were cropped by the farmer, the field contained large patches of bare crusted soil, which were selected for installing the experimental plots.

Long-term average annual rainfall at Kakassi is $450 \mathrm{~mm}$. Annual temperature variation is in the range of $25-35^{\circ} \mathrm{C}$. The soil is classified as vertic Haplustept (Soil Survey Staff 1998), with almost neutral $\mathrm{pH}$, no exchangeable aluminum and relatively high clay content (Table 1 ). The vegetation was an open bush with scattered trees. The experimental field was located on bare soil in a fallow, with scattered patches of cropped areas less affected by erosion. The field had been an uncultivated fallow for more than 10 years prior to the installation of the experiment.

\section{Experimental layout}

(1) On-station (at Sadoré), the effects of amendment type (millet straw and cattle manure) and rate of application $\left(1,3\right.$, and $\left.5 \mathrm{tha}^{-1}\right)$ on dry matter production of millet (Pennisetum glaucum L. $R$. Br) were evaluated in zai pits under controlled irrigation. The field was sprinkler-irrigated uniformly throughout the growing period at a weekly rate of $20 \mathrm{~mm}$. The experimental design was a randomised complete block design (RCBD) + control non-amended pit and a control non-amended flat, replicated four times. A local millet variety 'Sadoré local' (120 days growing cycle) was sown on 17 March 1999 and harvested on 25 May before grain production to avoid interference of rain with the treatments, but also due to the photosensitivity of the crop. Therefore only dry matter production was evaluated.

(2) On-farm, the effect of planting technique (planting on flat vs. planting in zai pits) and amendment type (millet straw and cattle manure) on millet growth and development was studied. At both sites, the experimental design was a RCBD + control (no organic amendment) with four replications, The millet variety 'Sadoré local' was sown at Damari on 29 June in 1999 and 26 June in 2000 and harvested at maturity (Table 2). At Kakassi a local millet variety 'Darinkoba' (120 days to maturity) was sown on 1 July in both years and harvested at maturity (Table 2). In all experiments, planting density was 10,000 pockets per ha. They were thinned to three plants per pocket approximately 3 weeks after planting.

Plant establishment was delayed at Damari in 1999 due to heavy rains (sand covered the young

Table 2. Details experiments at Damari and Kakassi 1999 and 2000.

\begin{tabular}{|c|c|c|c|c|}
\hline & \multicolumn{2}{|l|}{ Damari } & \multicolumn{2}{|l|}{ Kakassi } \\
\hline & 1999 & 2000 & 1999 & 2000 \\
\hline \multicolumn{5}{|l|}{ Plot size: $6 \mathrm{~m} \times 6 \mathrm{~m}$} \\
\hline \multicolumn{5}{|c|}{ Zai pits digging: 12 May at Damari and 29 May at Kakassi in both years } \\
\hline Amendment application & 24-May & 7-Jun & 4-Jun & 12-Jun \\
\hline Missing hills re-sowing & 14 DAS & $10 \mathrm{DAS}$ & 15 DAS & 13 DAS \\
\hline Plant thinning & 22 DAS & $22 \mathrm{DAS}$ & 22 DAS & $20 \mathrm{DAS}$ \\
\hline
\end{tabular}

DAS, Days after sowing. 
seedlings in the zai), and at Kakassi in 2000 due to dry spells at the beginning of the rainy season.

On-farm, in both years, the rain started at the end of June at Damari (Figure 1a and c) with adequate rain for planting. Cumulative rainfall in both years (499 $\mathrm{mm}$ in 1999 and $425 \mathrm{~mm}$ in 2000) was below the long-term average $(550 \mathrm{~mm})$. At Kakassi it was $397 \mathrm{~mm}$ in 1999 and $490 \mathrm{~mm}$ in 2000 (Figures $1 \mathrm{~b}$ and d), compared to the longterm average of $450 \mathrm{~mm}$, with useful rainfall for planting received at the end of June. In both years and particularly in 2000, frequent dry spells (more than 1 week without rain) occurred.

\section{Data collection}

At harvest, total dry weight (on-farm and on-station experiments) as well as seed dry weight and harvest index (on-farm only) were recorded. Harvest index is the ratio of grain yield to aboveground dry matter. Grain samples were analysed for N, P and $\mathrm{K}$ in both years' on-farm trials. To study crop nutrient uptake during the cropping period in the
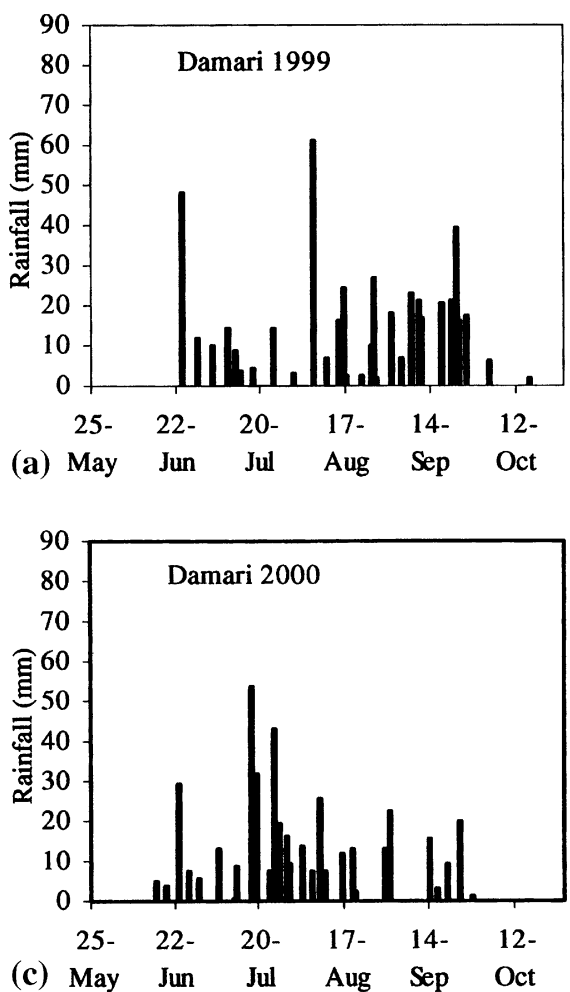

dry season trial, whole-plant samples were collected from two pockets in three replications every 3 weeks, starting three weeks after planting. Samples were cleaned, dried at $65^{\circ} \mathrm{C}$ for $48 \mathrm{~h}$; weighed and ground to pass a sieve of $1 \mathrm{~mm}$ mesh size. Subsamples of $5 \mathrm{~g}$ were analysed for total $\mathrm{N}, \mathrm{P}$ and $\mathrm{K}$, following a digestion according to the Kjeldahl method (Houba et al. 1995). Total N was determined with an auto-analyzer using the colorimetric method based on the Bertholet reaction. Total $\mathrm{P}$ was determined with the colorimetric method based on the phosphomolybdate complex, reduced with ascorbic acid and total $\mathrm{K}$ with flame emission spectrophotometry. To study water use, soil moisture profiles were measured weekly at $15 \mathrm{~cm}$ intervals down to $240 \mathrm{~cm}$ depth using a Didcot neutron probe (Didcot Instrument Company Limited). Two $48 \mathrm{~mm}$ inner diameter aluminum access tubes were installed in each plot, one tube between the hills, the other in the pocket close to the plant. At Damari, the depth of the shallowest tube was restricted to $45 \mathrm{~cm}$ due to the presence of a lateritic layer, while the deepest reached $300 \mathrm{~cm}$. At Kakassi the depths were, respectively, 100 and $165 \mathrm{~cm}$. The probe had
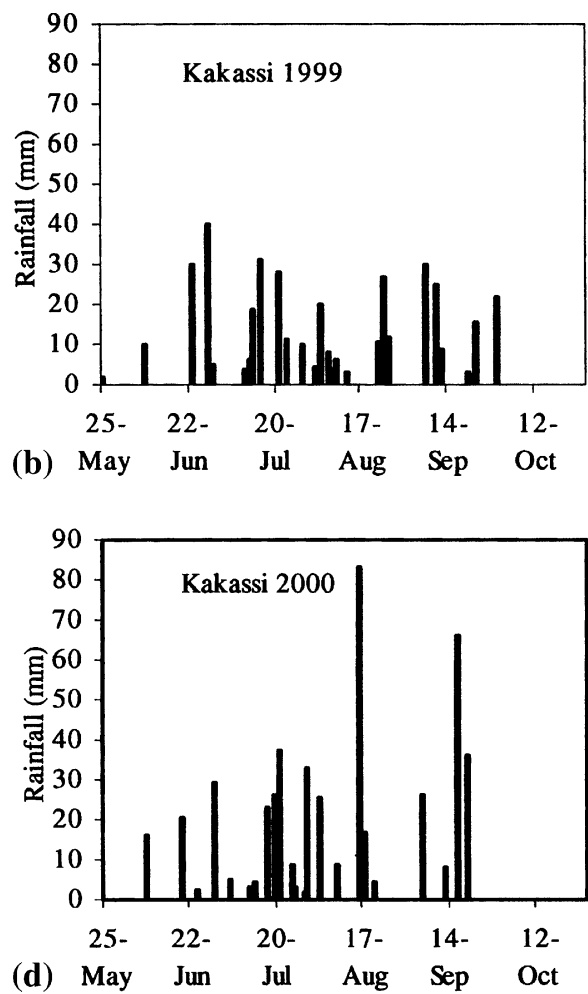

Figure 1. Daily rainfall at the experimental sites. Rainy seasons 1999 and 2000. 


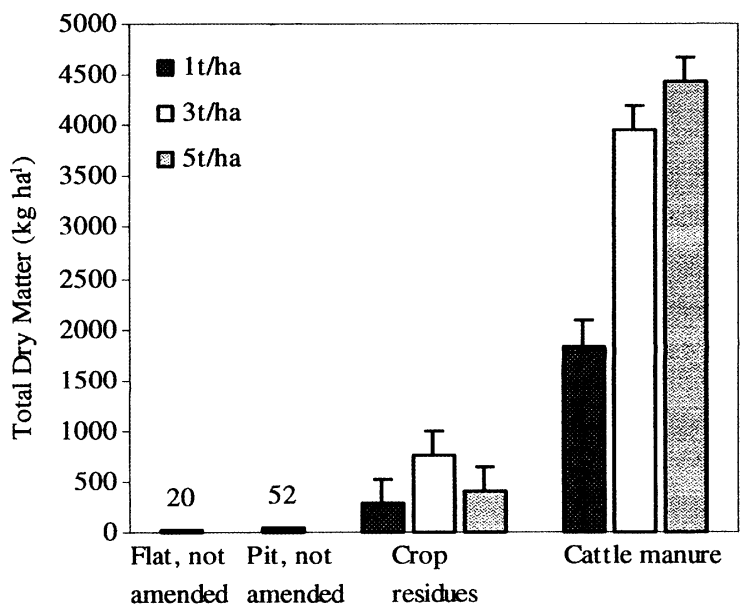

Figure 2. Millet dry matter production as affected by amendment type and rate in the zai system; Sadore 1999. Error bars are standard error of difference between means.

been calibrated in-situ for the soils of the experimental sites applying the gravimetric method. Data of the tubes installed between the millet pockets are reported in this paper.

From the neutron probe data, the volumetric soil water content and the stock of water in the soil profile were calculated. Water use efficiency was calculated as:

$$
\mathrm{WUE}=Y /\left(\sum(R-\Delta S)\right)
$$

where WUE, water use efficiency $\left(\mathrm{kg} \mathrm{mm}^{-1} \mathrm{ha}^{-1}\right)$; $Y$, yield $\left(\mathrm{kg} \mathrm{ha}^{-1}\right)$ (Total dry matter or grain); $\Delta \mathrm{S}$, change in soil water content between two dates of observation $(\mathrm{mm}) ; R$, total rainfall between two dates of observation $(\mathrm{mm})$.

From the data recorded at maturity the following parameters were calculated:

$\mathrm{N}, \mathrm{P}$ and $\mathrm{K}$ uptake:

$$
(C \times D) / 100\left(\mathrm{kgha}^{-1}\right),
$$

where $\mathrm{C}$, nutrient content in millet straw or grain $(\%)$ and $\mathrm{D}$, dry matter or grain yield at sampling $\left(\mathrm{kg} \mathrm{ha}^{-1}\right)$.

Agronomic Efficiency (AE):

$\mathrm{AE}=(\Delta \mathrm{yield} /$ Quantity of nutrient applied $)$

$$
\left(\mathrm{kg} \mathrm{kg}^{-1}\right)
$$

where $\Delta$ yield, the difference in yield obtained between the treated plot and the control (no amendment).
Nutrient Utilization Efficiency (NUE) (Christianson and Vlek 1991):

$$
\mathrm{NUE}=(\text { Yield } / \text { Total nutrient absorbed })
$$

$$
\left(\mathrm{kg} \mathrm{kg}^{-1}\right)
$$

where Yield, millet straw or grain yield in $\left(\mathrm{kg} \mathrm{ha}^{-1}\right)$; Total nutrient absorbed, total nutrient uptake in millet straw or grain $\left(\mathrm{kg} \mathrm{ha}^{-1}\right)$.

The statistical analysis was done with the ANOVA procedure of the statistical software GENSTAT $^{\circledR} 6.1$ (Lawes Agricultural Trust 2000). Due to the large differences between the amended plot and the controls, at a first step a restriction was put on the control plots data to analyse the amended plots. At a second step, the amended plots were restricted to analyse the control plots. The interpretation of results was done accordingly. The data of the on-farm trials were analysed for each site and year individually, and subsequently pooled and analysed as a split plot to compare the effect of the treatments in the two environments for the 2 years.

\section{Results}

\section{Dry matter production at Sadoré}

On-station, millet total dry matter (TDM) in the non-amended zai pit and the non-amended flat planting was very low (52 and $20 \mathrm{~kg} \mathrm{ha}^{-1}$, respectively (sed $= \pm 32$ ); Figure 2 ). Organic amendment application increased TDM production. Cattle manure was more effective than millet straw (3957 vs. $756 \mathrm{~kg} \mathrm{ha}^{-1}-$ sed $= \pm 239$ (Figure 2) when applied at $3 \mathrm{t} \mathrm{ha}^{-1}$ ). Furthermore, millet straw gave highest TDM at $3 \mathrm{tha}^{-1}$, while animal manure gave $12 \%$ more dry matter at $5 \mathrm{t} \mathrm{ha}^{-1}$.

Grain yield and total dry matter production on-farm

Effect of planting technique. Millet total dry matter (TDM) and grain production on flat planted control plots were very low to moderate at both sites in both years (grain yields $0.9-118 \mathrm{~kg} \mathrm{ha}^{-1}$; Table 3 ). With the zai technique grain yields were 3-4 times higher (and 19 times in one situation), 
Table 3. Effect of planting technique on millet grain and dry matter yield in un-amended plots; Damari and Kakassi, rainy season 1999 and 2000; values averaged over all treatments.

\begin{tabular}{|c|c|c|c|c|c|c|c|c|}
\hline \multirow[t]{3}{*}{ Sowing technique } & \multicolumn{4}{|c|}{ Grain yield $\left(\mathrm{kg} \mathrm{ha}^{-1}\right)$} & \multicolumn{4}{|c|}{ Total dry matter $\left(\mathrm{kg} \mathrm{ha}^{-1}\right)$} \\
\hline & \multicolumn{2}{|l|}{1999} & \multicolumn{2}{|l|}{2000} & \multicolumn{2}{|l|}{1999} & \multicolumn{2}{|l|}{2000} \\
\hline & Damari & Kakassi & Damari & Kakassi & Damari & Kakassi & Damari & Kakassi \\
\hline Zai & 17 & 434 & 19 & 388 & 303 & 2125 & 213 & 1938 \\
\hline Flat & 0.9 & 118 & 6 & 94 & 96 & 752 & 101 & 768 \\
\hline $\operatorname{Sed}( \pm)$ & 6.4 & 105.8 & 10.0 & 54.8 & 77.3 & 405.0 & 72.8 & 251.7 \\
\hline Fprob & 0.08 & 0.06 & $>0.05$ & 0.013 & 0.07 & 0.04 & $>0.05$ & 0.007 \\
\hline
\end{tabular}

Sed, standard error of difference between means.

Table 4. Effect of planting technique on millet grain yield and total dry matter production in plots amended with organic matter (average); Damari and Kakassi 1999 and 2000; values averaged over all treatments.

\begin{tabular}{|c|c|c|c|c|c|c|c|c|}
\hline \multirow[t]{3}{*}{ Sowing technique } & \multicolumn{4}{|c|}{ Grain yield $\left(\mathrm{kg} \mathrm{ha}^{-1}\right)$} & \multicolumn{4}{|c|}{ Total dry matter $\left(\mathrm{kg} \mathrm{ha}^{-1}\right)$} \\
\hline & \multicolumn{2}{|l|}{1999} & \multicolumn{2}{|l|}{2000} & \multicolumn{2}{|l|}{1999} & \multicolumn{2}{|l|}{2000} \\
\hline & Damari & Kakassi & Damari & Kakassi & Damari & Kakassi & Damari & Kakassi \\
\hline Zai, amended & 662 & 628 & 488 & 637 & 3096 & 3800 & 1824 & 3593 \\
\hline Flat, amended & 416 & 366 & 292 & 389 & 1881 & 2382 & 1346 & 1704 \\
\hline $\operatorname{Sed}( \pm)$ & 142.9 & 84.1 & 47.7 & 143.5 & 456.9 & 490.0 & 135.6 & 448.2 \\
\hline Fprob & $>0.05$ & 0.012 & 0.003 & $>0.05$ & 0.026 & 0.018 & 0.006 & 0.002 \\
\hline
\end{tabular}

Sed, standard error of difference between means.

illustrating the contribution of the water harvesting effects of the zai technique.

The overall tendency observed across years and sites in the amended plots was that grain yield and total dry matter in the zai were higher than on flat, with the differences in grain yield statistically significant at Kakassi in 1999 and at Damari in 2000 (Table 4), which may be due to the drier conditions in these years that enlarged the positive effect of the zai at the two sites.

Effect of amendment. In both years at both sites, cattle manure significantly increased the positive effect of the zai technique expressed in terms of straw yield, grain yield and total dry matter, but millet straw did not (Figures 3 and 4; Table 5). Millet straw application was more effective at Kakassi than at Damari (Table 5). The difference between both types of amendment was larger at Damari than at Kakassi (Table 5) with a 2- to 5fold grain yield increase at Kakassi and Damari, respectively, when manure application is compared to millet straw, indicating a better response to manure application on the more degraded soils (Damari). Cattle manure was more effective in
1999 than in 2000 in terms of dry matter production (Table 6).

Zai increased the harvest index mainly in 2000 (Table 7), a year characterized by intermittent dry spells that may have induced poor grain filling in contrast with 1999, a year with relatively better rainfall distribution. The zai was able to alleviate the effect of the frequent dry spells in the rainy season 2000. In addition, the better results of millet straw application at Kakassi compared to Damari may be attributed to the moderate soil fertility level of the soil at Kakassi (Table 1), that may have compensated for the nutrient deficiency in the millet straw applied (Table 8)

Nutrient uptake, nutrient utilization efficiency, and agronomic efficiency

On-station. All parameters were calculated on dry matter basis as the plants were harvested before grain setting. Nutrient uptake increased throughout the cropping period and was higher in manure-amended plots than in plots with millet 


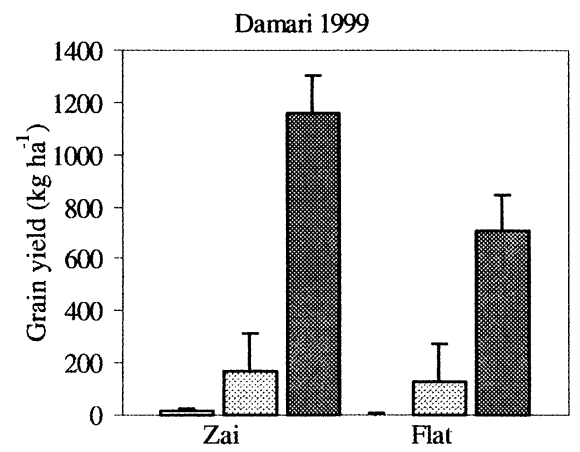

(a) $\square$ Control $⿴ 囗 ⿱ 一 一)$ Manure

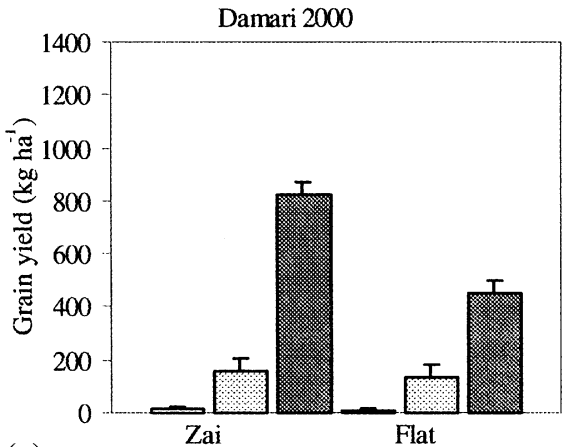

(c)

口Control 둘 Manure
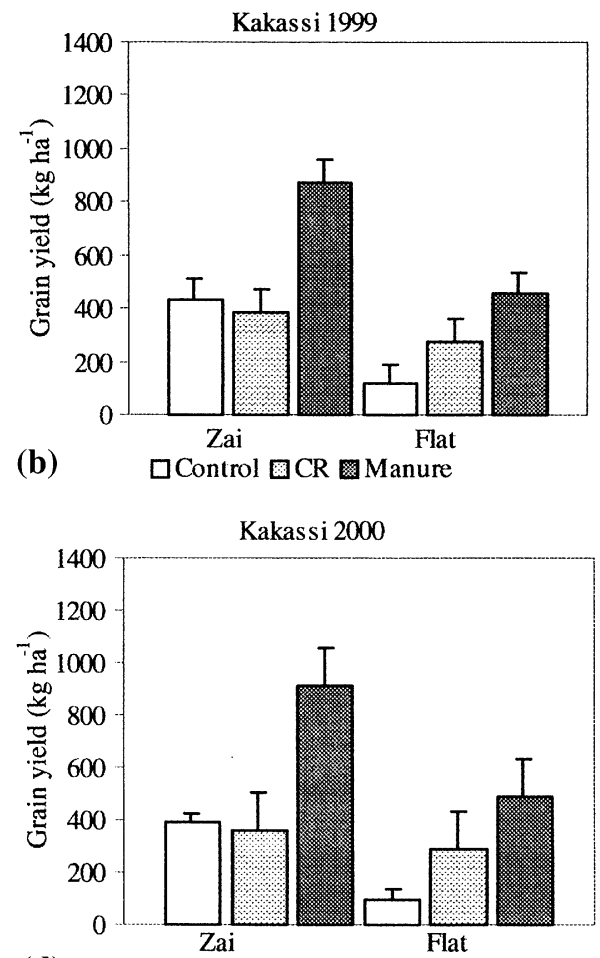

(d) $\quad$ Control $\mathrm{OCR}$ 圆 Manure

Figure 3. Millet grain yield as affected by sowing technique and amendment type. Damari and Kakassi, rainy seasons 1999 and 2000. $\mathrm{CR}$, millet straw. Error bars are standard error difference between means.

Table 5. Millet production characteristics as affected by amendment type at Damari and Kakassi; values averaged over treatments and years.

\begin{tabular}{llccr}
\hline Sites & Amendment & Straw yield $\left(\mathrm{kg} \mathrm{ha}^{-1}\right)$ & Grain yield $\left(\mathrm{kg} \mathrm{ha}^{-1}\right)$ & Total biomass $\left(\mathrm{kg} \mathrm{ha}{ }^{-1}\right)$ \\
\hline \multirow{2}{*}{ Damari } & Straw & 567 & 146 & 839 \\
& Manure & 2014 & 783 & 3234 \\
\multirow{2}{*}{ Kakassi } & Straw & 1184 & 327 & 1772 \\
& Manure & 2735 & 683 & 3968 \\
& Sed $( \pm)$ & 185.4 & 79.4 & 289.0 \\
& Fprob & $>0.05$ & 0.017 & $>0.05$ \\
\hline
\end{tabular}

Sed, standard error of difference between means.

Table 6. Millet production characteristics as affected by amendment type in 1999 and 2000; values averaged over all treatments and sites.

\begin{tabular}{llccc}
\hline Year & Amendment & Straw yield $\left(\mathrm{kg} \mathrm{ha}^{-1}\right)$ & Grain yield $\left(\mathrm{kg} \mathrm{ha}^{-1}\right)$ & Total biomass $^{\mathrm{a}}\left(\mathrm{kg} \mathrm{ha}^{-1}\right)$ \\
\hline \multirow{2}{*}{2999} & Straw & 960 & 239 & 1400 \\
& Manure & 2882 & 797 & 4180 \\
& Straw & 791 & 233 & 1211 \\
& Manure & 1867 & 669 & 3022 \\
& Sed $( \pm)$ & 185.4 & 79.4 & 289.0 \\
& Fprob & 0.003 & $>0.05$ & 0.023 \\
\hline
\end{tabular}

Sed, standard error of difference between means.

${ }^{\mathrm{a}}$ Total biomass exceeds the sum of straw yield and grain yield, because it corresponds to the total of straw yield and head yield (the yield of the reproductive part before threshing). 

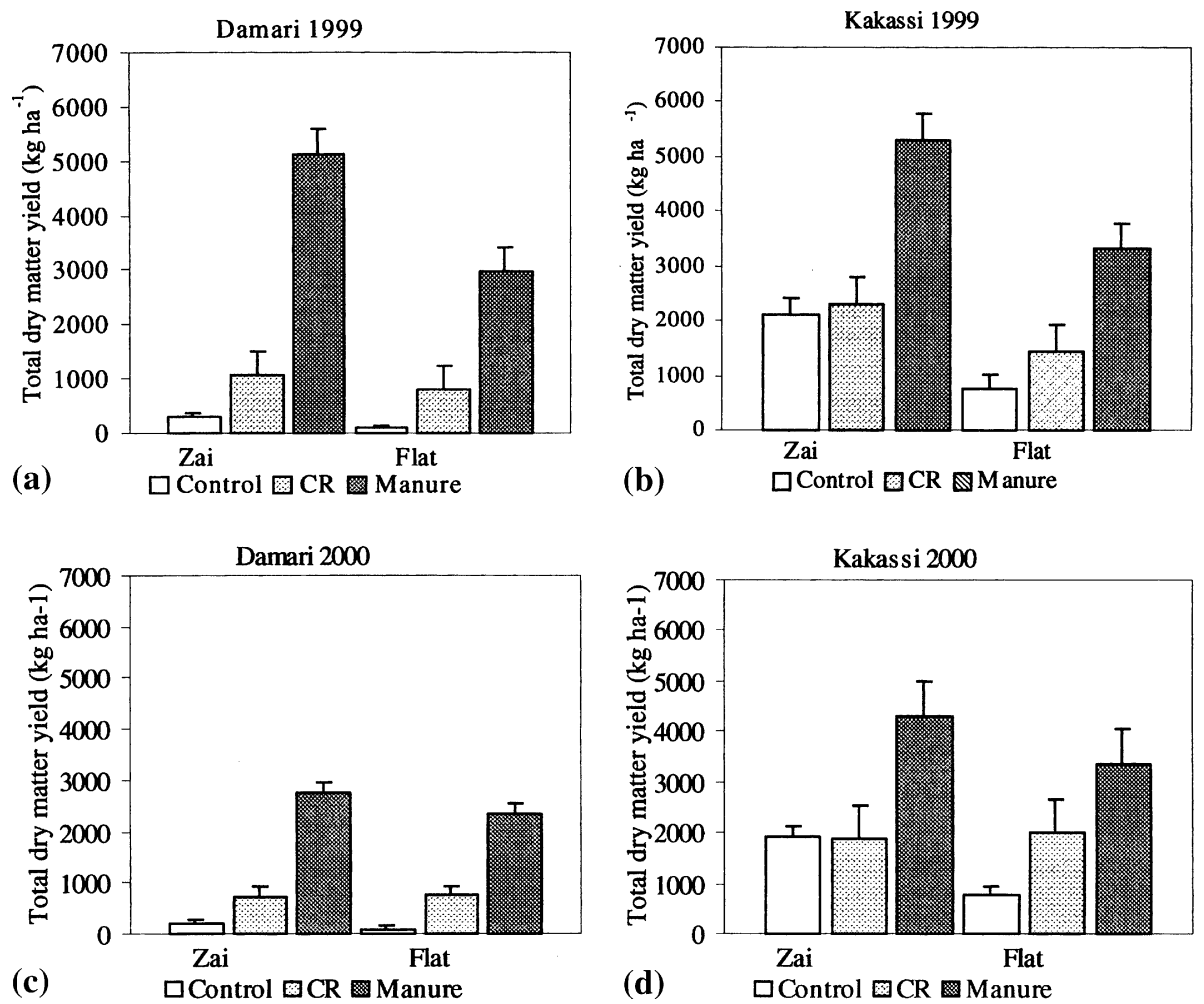

Figure 4. Millet total dry matter production as affected by sowing technique and amendment type. Damari and Kakassi, rainy seasons 1999 and 2000. CR, millet straw. Error bars are standard error of difference means.

straw (Figure 5); it was higher at higher rates of amendment application. The agronomic efficiency of manure was higher than that of millet straw (left side of Table 9) but the nutrient utilization efficiency of millet straw was higher than that of manure, particularly so for $\mathrm{P}$ and $\mathrm{K}$ (right side of Table 9). For both amendments, the higher the rate of application, the lower the agronomic efficiency (Table 10). These findings indicate that manure application increased nutrient uptake compared to millet straw, which was not efficiently used in the present study.

On-farm. At both sites in both years, a strong effect of amendment type on nutrient uptake was observed across years and sites (Figure 6). Nutrient uptake in the zai was higher than in flat planting although it was statistically significant only at Kakassi in 1999 and at Damari in 2000 (Figure $7 \mathrm{~b}$ and c). Total rainfall was far below the long-term average at Kakassi in 1999 and at Damari in 2000 (Figure 1), which led to a strong effect of the zai on nutrient uptake, which was also evident in the control plots at Kakassi (Figure 8). Therefore, the more favorable moisture conditions in the zai stimulated nutrient uptake and led to higher yields. No effect of planting technique and amendment type was observed on nutrient utilization efficiency except for Damari in 2000, where $\mathrm{N}$ utilization was more efficient under zai than under flat planting (55 vs. $51 \mathrm{~kg} \mathrm{~kg}^{-1}$ ). Straw $\mathrm{P}$ and $\mathrm{K}$ were also more efficiently utilized than

Table 7. Effect of sowing technique on millet harvest index.

\begin{tabular}{lcclll}
\hline Sowing technique & \multicolumn{2}{l}{ Harvest index } & & \\
\cline { 2 - 3 } & \multicolumn{1}{l}{1999} & & & 2000 & \\
\cline { 2 - 3 } \cline { 5 - 6 } & Damari & Kakassi & & Damari & Kakassi \\
\hline Zai & 0.19 & 0.17 & & 0.25 & 0.21 \\
Flat & 0.18 & 0.16 & & 0.20 & 0.12 \\
Sed $( \pm)$ & 0.02 & 0.02 & & 0.02 & 0.02 \\
Fprob & $>0.05$ & $>0.05$ & 0.015 & 0.003
\end{tabular}

Sed, standard error of difference between means.

Damari and Kakassi, rainy seasons 1999 and 2000; values averaged over treatments. 
Table 8. Chemical characteristics of the amendments used in the study.

\begin{tabular}{lllll}
\hline Organic amendment & N (\%) & P (\%) & K (\%) & C/N \\
\hline & 1999 & & & \\
Millet straw & 0.83 & 0.10 & 0.98 & 50 \\
Manure & 1.74 & 0.82 & 0.86 & 20 \\
& 2000 & & & \\
Millet straw & 1.18 & 0.10 & 1.57 & 50 \\
Manure & 2.53 & 0.94 & 1.72 & 21 \\
\hline
\end{tabular}

manure $\mathrm{P}$ and $\mathrm{K}$ (553 vs. $337 \mathrm{~kg} \mathrm{~kg}^{-1}$, sed $= \pm 34.2$ and 178 vs. $165 \mathrm{~kg} \mathrm{~kg}^{-1}$, sed $= \pm 2.9$, respectively).

Zai increased grain yield produced per unit $\mathrm{N}(8$ vs. $5 \mathrm{~kg} / \mathrm{kg}$, sed $= \pm 0.8)$ and $\mathrm{K}\left(10\right.$ vs. $6 \mathrm{~kg} \mathrm{~kg}^{-1}$, sed $= \pm 1.1$ ) compared to flat; so is the effect of cattle manure compared to millet straw (9.4 vs. $3.7 \mathrm{~kg} / \mathrm{kg}$, sed $= \pm 0.8$ and 13.8 vs. $2.8 \mathrm{~kg} \mathrm{~kg}^{-1}$, sed $= \pm 1.1$ ), particularly at Damari in 2000 .

The pooled data show that in general nutrient concentration and uptake in the grain were higher in 1999 than in 2000, but the nutrients were more efficiently used in 2000 (Table 11) indicating that favorable rainfall distribution in 1999 favored nutrient uptake. Nitrogen, $\mathrm{P}$ and $\mathrm{K}$ concentration and uptake were higher at Kakassi than at Damari Table 12), resulting in higher grain yield except for Damari in 1999. But grain yield per unit of nutrient absorbed was higher at Damari than at Kakassi, which could be due to the better rainfall conditions at Damari which improved nutrient utilization efficiency.

\section{Rainfall use efficiency}

Rainfall was more efficiently used in the zai than in flat planting, even though some site and yearspecific trends were observed. At Damari in 1999 and at Kakassi in 2000 with relatively high total rainfall, the effect of planting technique on water use efficiency was not statistically significant (Table 13), whereas at Kakassi in 1999 and at Damari in 2000, seasons with lower total rainfall,

Table 9. Agronomic efficiency and nutrient utilization efficiency as affected by amendment type; Sadoré, dry season 1999 ( $\left.\mathrm{kg} \mathrm{kg}^{-1}\right)$; values averaged over treatments.

\begin{tabular}{|c|c|c|c|c|c|c|}
\hline \multirow[t]{2}{*}{ Amendment } & \multicolumn{3}{|c|}{ Agronomic efficiency } & \multicolumn{3}{|c|}{ Nutrient utilization efficiency } \\
\hline & $\mathrm{N}$ & $\mathrm{P}$ & $\mathrm{K}$ & $\mathrm{N}$ & $\mathrm{P}$ & $\mathrm{K}$ \\
\hline Millet straw & 11 & 92 & 9 & 38 & 785 & 25 \\
\hline Cattle manure & 38 & 81 & 78 & 39 & 516 & 22 \\
\hline Sed $( \pm)$ & 2.7 & 6.6 & 5.4 & 0.7 & 37.2 & 0.7 \\
\hline Fprob & $<0.001$ & $>0.05$ & $<0.001$ & $>0.05$ & $<0.001$ & $<0.001$ \\
\hline Flat non-amended & & & & 40 & 887 & 52 \\
\hline zai non-amended & & & & 37 & 731 & 26 \\
\hline Sed $( \pm)$ & & & & 1.0 & 84.4 & 0.8 \\
\hline Fprob & & & & 0.08 & $>0.05$ & $<0.001$ \\
\hline
\end{tabular}

Sed, standard error of difference between means.

Table 10. Agronomic efficiency and nutrient utilization efficiency as affected by amendment rate of application; Sadoré, dry season $1999\left(\mathrm{~kg} \mathrm{~kg}^{-1}\right)$; values averaged over both amendments types.

\begin{tabular}{|c|c|c|c|c|c|c|}
\hline \multirow[t]{2}{*}{ Rates } & \multicolumn{3}{|c|}{ Agronomic efficiency } & \multicolumn{3}{|c|}{ Nutrient utilization } \\
\hline & $\mathrm{N}$ & $\mathrm{P}$ & $\mathrm{K}$ & $\mathrm{N}$ & $\mathrm{P}$ & $\mathrm{K}$ \\
\hline $1 \mathrm{t} \mathrm{ha}^{-1}$ & 33 & 118 & 57 & 39 & 724 & 26 \\
\hline $3 \mathrm{t} \mathrm{ha}^{-1}$ & 25 & 93 & 43 & 39 & 659 & 24 \\
\hline $5 \mathrm{t} \mathrm{ha}^{-1}$ & 16 & 47 & 30 & 38 & 569 & 21 \\
\hline Sed $( \pm)$ & 3.3 & 8.0 & 6.6 & 0.9 & 45.5 & 0.9 \\
\hline Fprob & 0.002 & $<0.001$ & 0.008 & $>0.05$ & 0.021 & $<0.001$ \\
\hline
\end{tabular}

Sed, standard error of difference between means. 

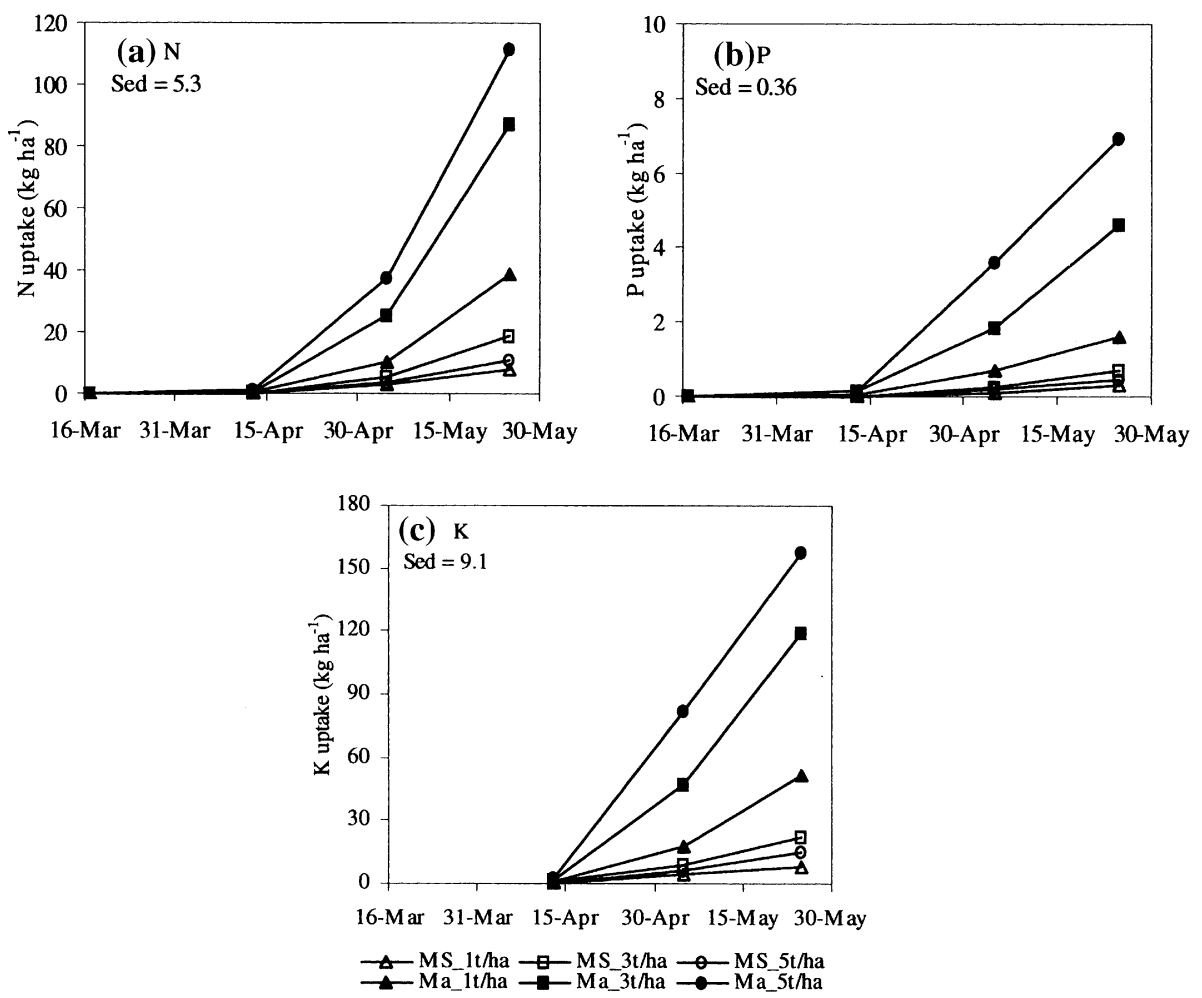

Figure 5. Millet nutrient uptake dynamics during growth; Sadoré 1999. (Crop allowed growing for 2 months and half). MS, millet straw; Ma, manure.

water use efficiency in zai was higher than in flat planting (1.9 vs. $1.1 \mathrm{~kg} / \mathrm{mm}$ at Kakassi and 1.4 vs. $0.8 \mathrm{~kg} / \mathrm{mm}$ at Damari). Therefore, the effectiveness of the technology is more evident under drier conditions. Water use efficiency was higher with manure application than with millet straw for both sites and years (Table 14).

\section{Discussion}

\section{Grain yield and total dry matter production}

Farmers of the Sahel hardly use any inorganic fertilizer. According to Bationo et al. (2003), farmers in the region apply less than $5 \mathrm{~kg} \mathrm{ha}^{-1}$ of plant nutrients, and subsidies on mineral fertilizers have been removed which has increased unsustainable nutrient mining. Therefore, the introduction of organic amendments is important to meet the crops' nutritional requirements and sustain soil fertility. These amendments are even more important for resource-poor farmers who use them in combination with the zai technique. The organic amendments induced better plant growth and development, which resulted in relatively high TDM production. Grain and total dry matter yields with millet straw amended plots were lower than with cattle manure which is consistent with lower nutrient contents in the millet straw amendment, especially in terms of $\mathrm{N}$ and $\mathrm{P}$. Bationo and Mukwenye (1991), Michels et al. (1995), Pichot et al. (1981) and Pieri (1986) have reported the beneficial effect of crop residues and cattle manure application on millet yield. The present results with cattle manure support this view, but the $815 \mathrm{~kg} \mathrm{ha}^{-1}$ total dry matter obtained with $3 \mathrm{t} \mathrm{ha}^{-1}$ crop residue application was far below the $3673 \mathrm{~kg} \mathrm{ha}^{-1}$ reported by Buerkert et al. (2000) for Sadoré in Niger with $500 \mathrm{~kg} \mathrm{ha}^{-1}$ surfaceapplied crop residues. However, in the latter study the mulch may have reduced wind erosion, sand blasting and burial of seedlings (Michels et al. 1995). Furthermore, millet straw in the zai pit may 
locally have increased $\mathrm{N}$ immobilization due to the high $\mathrm{C} / \mathrm{N}$ ratio.

Increasing the rate of manure application from 3 to $5 \mathrm{t} \mathrm{ha}^{-1}$ did not produce a proportional yield increase, which suggests that the lower rate is preferable from the farmer's viewpoint; however, further investigations are needed as this also depends on the rainfall. Grain yield was substantially higher in the non-amended zai at Kakassi than in the control (flat planting). Except for extractable P, soil fertility at Kakassi was much higher than at Damari; thus, the increased water availability in the zai pits at this site alleviated the primary constraint for crop production, water. However, in both years, the zai pits accumulated wind-blown sand and plant debris before planting, which may have constituted an additional nutrient source for the millet.

The combination of cattle manure application with zai always resulted in grain yield increases. This illustrates the combined effect of the readily available nutrients from the cattle manure and the water harvested in the zai pits.

\section{Nutrient uptake, utilization and agronomic efficiency}

Higher nutrient availability stimulated crop growth; but crop yield per unit of nutrient absorbed was lower under good nutritional conditions indicating that zai may be relatively less efficient on good soils. Also, nutrient utilization efficiency decreased with increased amendment rate of application. Therefore, to make better use of the limited quantity of available organic matter, it is necessary to identify suitable application rates for the zai system. According to Williams et al. (1995), farmers in Niger can apply manure only to $10-40 \%$ of their cultivated fields each year, if they rely on their household livestock. Using good quality compost may help to overcome part of this constraint.

Penning de Vries and Djiteye (1982) and Breman and De Wit (1983) suggested that nutrient availability, but not water availability was the most important limiting factor for agricultural
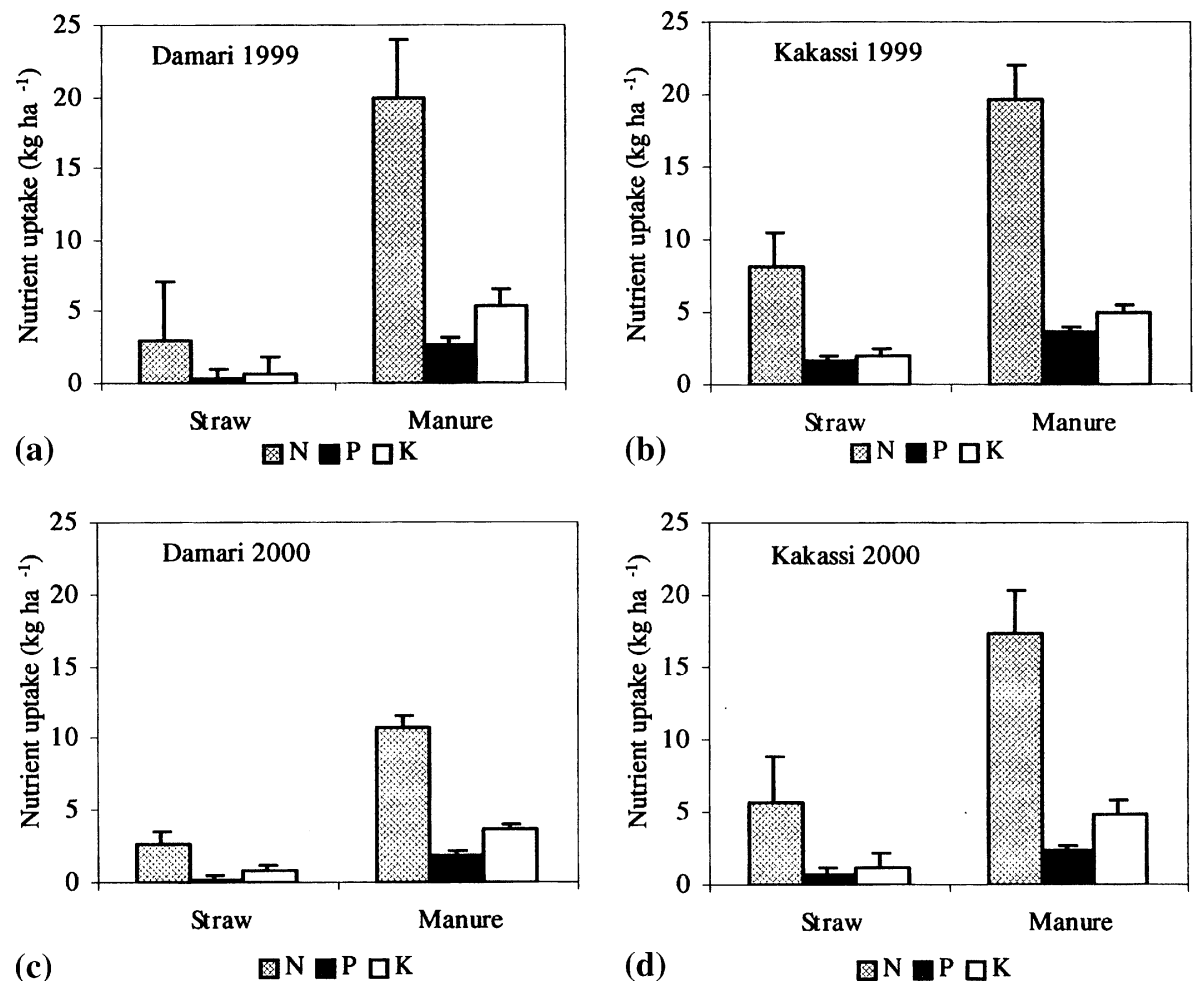

Figure 6. Millet nutrient uptake as affected by amendment type in 1999 and 2000 at Damari and Kakassi. Error bars are standard error of difference between means. 

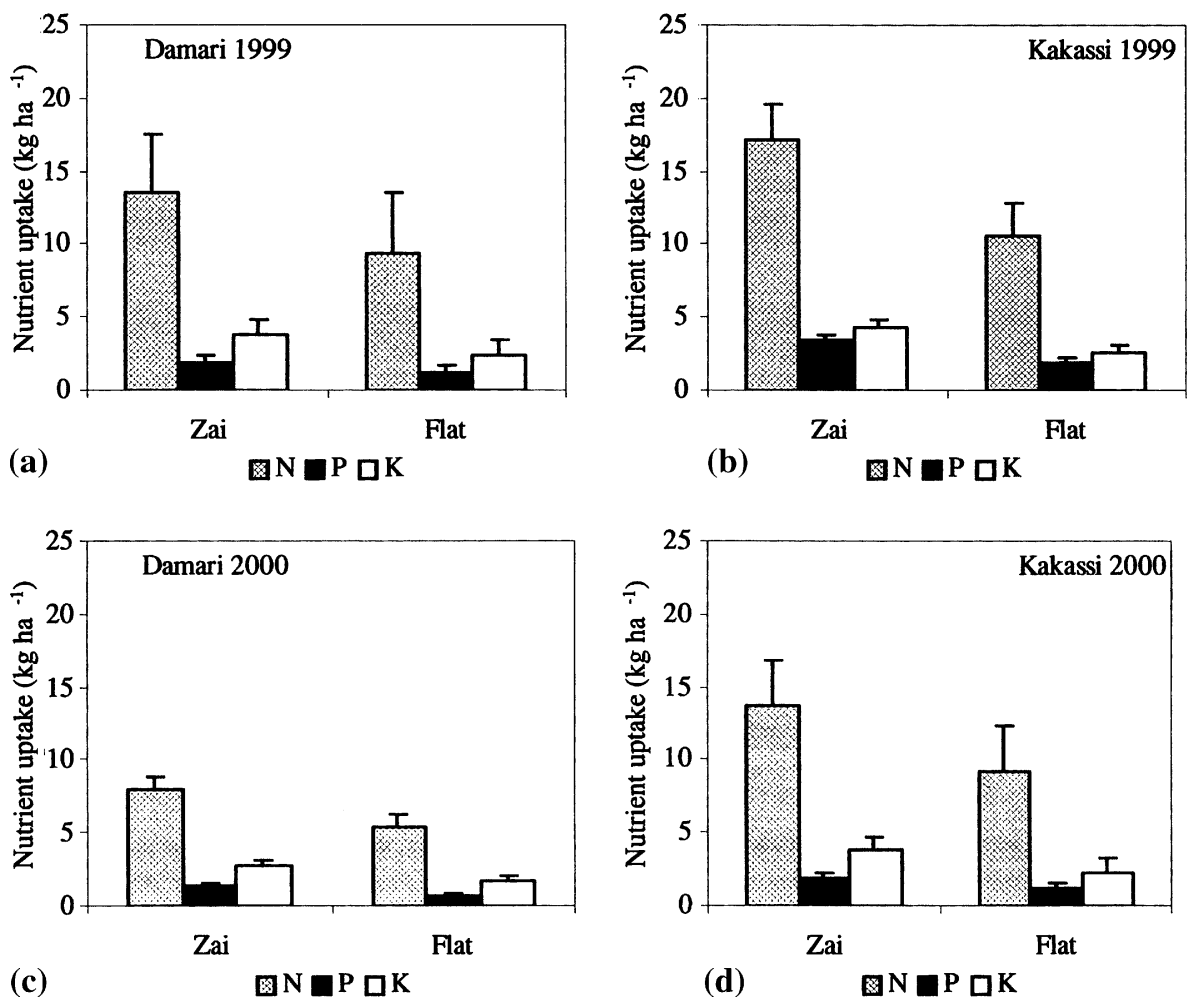

Figure 7. Millet nutrient uptake as affected by planting technique in 1999 and 2000 at Damari and Kakassi. Error bars are standard error of difference between means.

production in the Sahel. However, Bationo et al. (1990) reported a poor response of millet to $\mathrm{N}$ application in dry years, and Payne et al. (1995) argued that plant nutrients in agriculture in the Sahel should be considered in relation to the water component. Many studies have shown the strong interaction between the availability of water and plant nutrients, and changing one of these factors can greatly affect the response to the other. Increased water supply not only directly enhances fertilizer response but also may affect indigenous nutrient availability and efficiency of utilization, Campbell et al. (1977), Campbell and Paul (1978), Wright and Black (1978) and Payne et al. (1995)
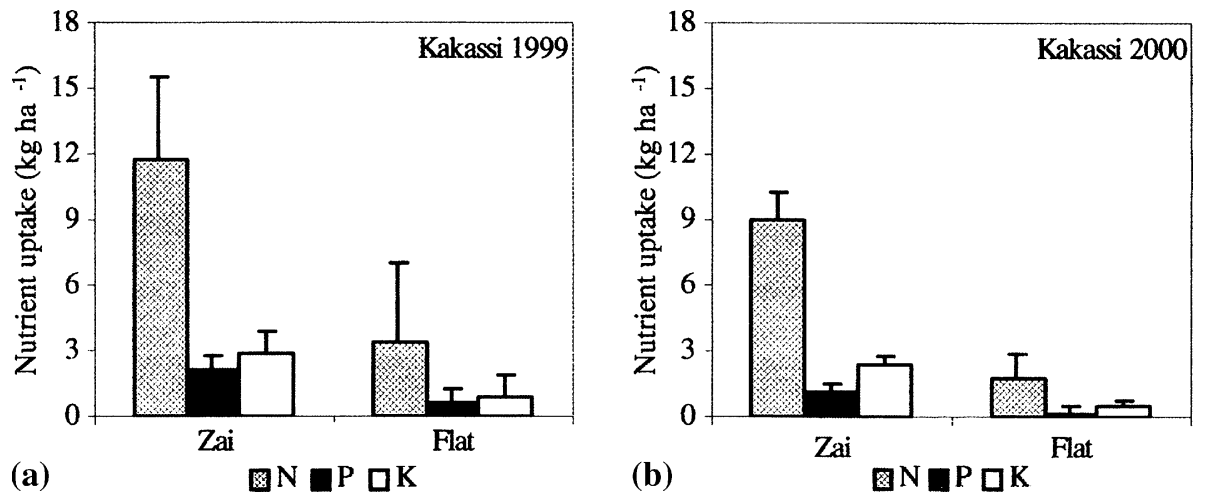

Figure 8. Millet nutrient uptake as affected by planting technique at Kakassi in control plots. Error bars are standard error of difference betweeen means. 
Table 11. Millet chemical characteristics in the two experimental years; values averaged over treatments and sites.

\begin{tabular}{|c|c|c|c|c|c|c|c|c|c|c|c|c|}
\hline \multirow[t]{2}{*}{ Year } & \multicolumn{3}{|c|}{$\%$ Nutrient in grain } & \multicolumn{3}{|c|}{$\begin{array}{l}\text { Grain nutrient uptake } \\
\left(\mathrm{kg} \mathrm{ha}^{-1}\right)\end{array}$} & \multicolumn{3}{|c|}{$\begin{array}{l}\text { Nutrient utilization efficiency } \\
\left(\mathrm{kg} \mathrm{kg}^{-1}\right)\end{array}$} & \multicolumn{3}{|c|}{$\begin{array}{l}\text { Agronomic efficiency } \\
\left(\mathrm{kg} \mathrm{kg}^{-1}\right)\end{array}$} \\
\hline & $\mathrm{N}$ & $\mathrm{P}$ & $\mathrm{K}$ & $\mathrm{N}$ & $\mathrm{P}$ & $\mathrm{K}$ & $\mathrm{N}$ & $\mathrm{P}$ & $\mathrm{K}$ & $\mathrm{N}$ & $\mathrm{P}$ & $\mathrm{K}$ \\
\hline 1999 & 2.5 & 0.4 & 0.6 & 12.7 & 2.1 & 3.3 & 40 & 266 & 157 & 9 & 29 & 17 \\
\hline 2000 & 2.5 & 0.3 & 0.6 & 9.1 & 1.3 & 2.6 & 48 & 395 & 182 & 5 & 22 & 7 \\
\hline Sed $( \pm)$ & 0.07 & 0.02 & 0.04 & 1.74 & 0.31 & 0.44 & 1.2 & 14.5 & 20.5 & 2.3 & 12.5 & 3.5 \\
\hline Fprob & $<0.001$ & $<0.001$ & $>0.05$ & 0.07 & 0.03 & $>0.05$ & $<0.001$ & $<0.001$ & $>0.05$ & $>0.05$ & $>0.05$ & 0.018 \\
\hline
\end{tabular}

Sed, standard error of difference between means.

Table 12. Millet chemical characteristics in the two experimental sites; values averaged over treatments and years.

\begin{tabular}{|c|c|c|c|c|c|c|c|c|c|c|c|c|}
\hline \multirow[t]{2}{*}{ Site } & \multicolumn{3}{|c|}{$\%$ Nutrient in grain } & \multicolumn{3}{|c|}{$\begin{array}{l}\text { Grain nutrient } \\
\left(\mathrm{kg} \mathrm{ha}^{-1}\right)\end{array}$} & \multicolumn{3}{|c|}{ Nutrient utilization efficiency } & \multicolumn{3}{|c|}{ Agronomic efficiency } \\
\hline & $\mathrm{N}$ & $\mathrm{P}$ & $\mathrm{K}$ & $\mathrm{N}$ & $\mathrm{P}$ & $\mathrm{K}$ & $\mathrm{N}$ & $\mathrm{P}$ & $\mathrm{K}$ & $\mathrm{N}$ & $\mathrm{P}$ & $\mathrm{K}$ \\
\hline Damari & 2.1 & 0.3 & 0.6 & 9.1 & 1.3 & 2.7 & 48 & 389 & 167 & 10 & 39 & 16 \\
\hline Kakassi & 2.5 & 0.4 & 0.6 & 12.7 & 2.1 & 3.3 & 41 & 273 & 171 & 5 & 12 & 9 \\
\hline Sed $( \pm)$ & 0.07 & 0.02 & 0.04 & 1.74 & 0.31 & 0.44 & 1.2 & 14.5 & 20.5 & 2.3 & 12.5 & 3.5 \\
\hline Fprob & 0.001 & 0.001 & $>0.05$ & 0.07 & 0.03 & $>0.05$ & $<0.001$ & $<0.001$ & $>0.05$ & 0.06 & 0.07 & 0.07 \\
\hline
\end{tabular}

Sed, standard error of difference between means.

Table 13. Millet rain use efficiency as affected by planting technique in 1999 and 2000 at Damari and Kakassi; values averaged over all treatments.

\begin{tabular}{|c|c|c|c|c|c|c|c|c|}
\hline \multirow[t]{3}{*}{ Sowing technique } & \multicolumn{4}{|c|}{ WUE - grain $\left(\mathrm{kg} \mathrm{mm}^{-1}\right)$} & \multicolumn{4}{|c|}{ WUE - dry matter $\left(\mathrm{kg} \mathrm{mm}^{-1}\right)$} \\
\hline & \multicolumn{2}{|l|}{1999} & \multicolumn{2}{|l|}{2000} & \multicolumn{2}{|l|}{1999} & \multicolumn{2}{|l|}{2000} \\
\hline & Damari & Kakassi & Damari & Kakassi & Damari & Kakassi & Damari & Kakassi \\
\hline Zai & 1.4 & 1.9 & 1.4 & 1.9 & 6.3 & 11.7 & 5.1 & 10.9 \\
\hline Flat & 0.8 & 1.1 & 0.8 & 1.1 & 3.8 & 7.5 & 3.8 & 4.7 \\
\hline Sed & 0.29 & 0.26 & 0.13 & 0.41 & 0.92 & 1.52 & 0.37 & 1.33 \\
\hline Fprob & $>0.05$ & 0.015 & 0.003 & 0.07 & 0.024 & 0.022 & 0.007 & 0.001 \\
\hline
\end{tabular}

Sed, standard error of difference between means.

Table 14. Millet rain use efficiency as affected by amendment type in 1999 and 2000 at Damari and Kakassi; values averaged over all treatments.

\begin{tabular}{|c|c|c|c|c|c|c|c|c|}
\hline \multirow[t]{3}{*}{ Amendment } & \multicolumn{4}{|c|}{ WUE - grain $\left(\mathrm{kg} \mathrm{mm}^{-1}\right)$} & \multicolumn{4}{|c|}{ WUE - dry matter $\left(\mathrm{kg} \mathrm{mm}^{-1}\right)$} \\
\hline & \multicolumn{2}{|l|}{1999} & \multicolumn{2}{|l|}{2000} & \multicolumn{2}{|l|}{1999} & \multicolumn{2}{|l|}{2000} \\
\hline & Damari & Kakassi & Damari & Kakassi & Damari & Kakassi & Damari & Kakassi \\
\hline Millet straw & 0.3 & 1.0 & 0.4 & 0.9 & 1.9 & 5.8 & 2.1 & 4.8 \\
\hline Manure & 1.9 & 2.0 & 1.8 & 2.1 & 8.2 & 13.3 & 6.7 & 10.8 \\
\hline Sed & 0.29 & 0.26 & 0.13 & 0.41 & 0.92 & 1.52 & 0.37 & 1.33 \\
\hline Fprob & $<0.001$ & 0.004 & $<0.001$ & 0.02 & $<0.001$ & $<0.001$ & $<0.001$ & 0.001 \\
\hline
\end{tabular}

Sed, standard error of difference between means. 
have reported that plants grown with adequate nutrient supply extend roots deeper than when grown in deficient conditions. Increased root proliferation increases the volume of soil colonized, thereby increasing the potential for water use and thus reducing the probability of plant growth being restricted by intermittent periods of drought (Brown, 1971). In the zai technique, water and nutrients are placed in the vicinity of plant roots. Therefore it favours crop growth and alleviates the adverse effects of the irregularly occurring dry spells. In addition, when cattle manure or other good quality amendments are used in the zai, they induce efficient water use compared to the traditional flat planting.

\section{Conclusions}

Zai is a strong tool to mitigate a major constraint to agricultural production in the Sahel, the limited total rainfall and its uneven distribution in time and space, because zai alleviates the effect of dry spells during plant growth, and improves rain use efficiency by a factor of two compared to traditional flat planting. This study confirms the results of former studies that substantial increases in TDM and grain yields are possible when using the zai technique. The effects are not only due to the water harvesting, but also due to the amendments, and they can be increased when using high-quality amendments. More than $1 \mathrm{t} \mathrm{ha}^{-1}$ millet grain yield was obtained from zai amended with cattle manure at a rate of $3 \mathrm{tha}^{-1}$. An additional $500 \mathrm{~kg} \mathrm{ha}^{-1}$ of grain were obtained by planting in zai compared to flat planting, an important gain to the farmers.

Zai and cattle manure application improved millet nutrient uptake, crop growth, and ultimately, yields. Economic yield per unit of nutrient applied under zai was higher than without zai.

Nevertheless, availability of good-quality organic amendments is a pre-requisite for the success of the technology on highly degraded soils such as at Damari. In this regard, the scarcity of animal dung presents a constraint to the use of the zai technology. However, farmers are generally able to prepare good quality compost using all kinds of domestic wastes, weeds, and leguminous residues before and during the onset of the rainy season (own observation), although there may be limits to this (cf. de Ridder et al. 2004). Also, total dry matter gain increased by $115 \%$ when increasing the manure application rate from 1 to $3 \mathrm{tha}^{-1}$, but only by $12 \%$ from a further increase to $5 \mathrm{t} \mathrm{ha}^{-1}$. This (and also the significant reduction in nutrient agronomic efficiency) shows that an optimal application rate should be around $3 \mathrm{t} \mathrm{ha}^{-1}$. Here, nevertheless, further work is needed to optimize the use of the limited available organic amendments.

\section{References}

Amissah-Arthur A., Mougenot B. and Loireau M. 2000. Assessing farmland dynamics and land degradation on Sahelian landscapes using remotely sensed and socioeconomic data. Intl J. Geograph. Inform. Sci. 14(6): 583-599.

Bationo A., Christianson C.B. and Baethgen W.E. 1990. Plant density and nitrogen fertilizer effects on pearl millet production in a sandy soil in Niger. Agron. J. 82: 290-295.

Bationo A. and Mokwunye A.U. 1991. Role of cattle manures and crop residue in alleviating soil fertility constraints to crop production: with special reference to the Sahelian and the Soudanian zone of West Africa. Fertil. Res. 29: 117-125.

Bationo A., Mokwunye U., Vlek P.L.G., Koala S. and Shapiro B.I. 2003. Soil fertility management for sustainable land use in the West African sudano-sahelian zone. In: Soil Fertility Management in Africa: A regional perspective. Academy Science Publisher \& Tropical Soil Biology and Fertility, pp. 253-292.

Breman H. and de Wit C.T. 1983. Rangeland productivity and exploitation in the Sahel. Science 221: 1341-1347.

Brown P.L. 1971. Water use and soil water depletion by dryland winter wheat as affected by nitrogen fertilization. Agron. J. 63: 43-46.

Buerkert A., Bationo A. and Dossa K. 2000. Mechanisms of residue mulch-induced cereal growth increases in West Africa. Soil Sci. Soc. Amer. J. 64: 346-358.

Campbell C.A. and Paul B.A. 1978. Effect of fertilizer N and soil moisture on mineralization, $\mathrm{N}$ recovery and A-values, under spring wheat grown in small lysimeters. Can. J. Soil Sci. 58: 39-51.

Campbell C.A., Davidson H.R. and Warder F.D. 1977. Effects of fertilizer $\mathrm{N}$ and soil water in yield, yield components, protein content and $\mathrm{N}$ accumulation in the aboveground parts of spring wheat. Can. J. Soil Sci. 57: 311-327.

Casenave A. and Valentin C. 1989. Les états de surface de la zone sahelienne; Influence sur l'infiltration. Les processus et les facteurs de réorganisation superficielle, Ed. ORSTOM. Institut Français de Recherche Scientifique pour le Développement en Coopération, Collection Didactiques, Paris, pp. 65-190.

Christianson C.B. and Vlek P.L.G. 1991. Alleviating soil fertility constraints to food production in west Africa: efficiency of nitrogen fertilizer applied to food crops. Fertil. Res. 29: 21-33.

de Ridder N., Breman H., van Keulen H. and Stomph T.J. 2004. Revisiting a 'cure against land hunger': soil fertility 
management and farming systems dynamics in the west African Sahel. Agricult. Sys. 80: 109-131.

Hassan A. 1996. Improved traditional planting pits in the Tahoua department, Niger. An example of rapid adoption by farmers. In: Reij C., Scoones I. and Toulmin C. (eds.), Sustaining the Soil. Indigenous Soil and Water Conservation in Africa. Earthscan Publisher, pp.56-61.

Houba V.J.G., Van de Lee J.J. and Novozamsky I. 1995. Soil and Plant Analysis, Part 5B, Syllabus 1995. In: Soil Analysis Procedures, Other Procedures. Department of Soil Science and Plant Nutrition, Wageningen Agricultural University.

Kaboré V. 1995. Amelioration de la production végétale des sols dégrades (zipelles) du Burkina Faso par la technique des poquets ("zai"). Ph.D. thesis, EPFL (no 1302), Lausanne, 201 pp.

Katyal J.C. and Vlek P.L.G. 2000. Desertification - concept, causes and amelioration, ZEF Discussion Paper on Development Policy 33, 65 pp.

Lawes Agricultural Trust 2000. GENSTAT ${ }^{\circledR} 6$ release 1. VSN International, Wilkinson House, Jordan Hills Road, Oxford, UK.

Michels K., Sivakumar M.V.K. and Allison B.E. 1995. Wind Erosion Control using Crop Residue: I. Effect on soil flux and soil properties. Field Crop. Res. 40: 101-110.

Oldeman L.R., Hakkeling R.T.A. and Sombroek W.G. 1990. World Map of the Status of Human-Induced Soil Degradation: An Explanatory Note, Revised edition. International Soil Reference and Information Centre, United Nation Environment Program, Wageningen, Nairobi.

Ouedraogo M. and Kaboré V. 1996. The "zai": a traditional technique for the rehabilitation of degraded land in the Yatenga, Burkina Faso. In: Reij C., Scoones I. and Toulmin C. (eds.), Sustaining the Soil. Indigenous Soil and Water Conservation in Africa. Earthscan Publisher, pp.80-92.

Payne W.A., Lloyd R., Arthur H., Onken B. and Wendt C.W. 1995. Nitrogen and phosphorus uptake in pearl millet and its relation to nutrient and transpiration efficiency. Agron. J. 87: 425-431.

Penning de Vries F.W.T. and Djiteye M.A. 1982. L'élevage et l'exploitation des paturages au Sahel. In: Penning de Vries
F.W.T. and Djiteye M.A. (eds.), La productivité des paturages Saheliens. Une étude des sols, des végétations et de l'exploitation de cette ressource naturelle. Centre for Agricultural Publication and Documentation, Wageningen, The Netherlands.

Pichot J., Sedogo M.P., Poulain J.L. and Arrivets J. 1981. Evolution de la fertilité d'un sol ferrugineux sous l'influence de fumures minérales et organiques. Agron. Trop. 36: 122133.

Pieri C. 1986. Fertilisation des cultures vivrières et fertilité des sols en agriculture paysanne sub-saharienne. Agron. Trop. 41: 1-20.

Roose E., Dugué P. and Rodriguez L. 1992. La G.C.E.S. Une nouvelle strategie de lutte anti-erosive appliquee a l' amenagement de terroirs en zone soudano- sahelienne du Burkina Faso. Revue Bois et Forêts des Tropiques 233: 49-62.

Roose E., Kaboré V. and Guenat C. 1993. Le“zai": Fonctionnement, limites et amélioration, d'une pratique traditionnelle africaine de réhabilitation de la végétation et de la productivité des terres dégradées en région soudano-sahelienne (Burkina Faso). Cahier de l'ORSTOM, Série Pédologie XXVIII(2): 59-173.

Soil Survey Staff 1998. Keys to Soil Taxonomy, 8th edition. USDA/NRCS.

Sundquist B. 2004. Land area data and aquatic area data; a compilation. Edition 1, March, 2004. http:/home.Alltel.net/ bsundquistl/laO.html [checked 5.12.2005].

West L.T., Wilding L.P., Landeck J.K. and Galhoun F.G. 1984. Soil Survey of the Icrisat Sahelian Center, Niger. Soil and Crop Science Department/TropSoils Texas A\&M System, College Station, Texas in cooperation with the International Crop Research Institute for the Semi-Arid Tropics.

Williams T.O., Powell J.M. and Fernandez-Rivera S. 1995. Manure availability in relation to sustainable food crop production in Semi-Arid West Africa: evidence from Niger. Quart. J. Intl Agricul. 34: 248-258.

Wright J.R. and Black A.L. 1978. Soil water use and recharge in a fertilized mixed prairie plant community. J. Range Manag. 31: 280-282. 